Marine Biology Research

June 2008, Volume 4, Issue 3, Pages 180 - 192

http://dx.doi.org/10.1080/17451000801898576

(c) 2008 Taylor \& Francis Group
Archimer http://www.ifremer.fr/docelec/ Archive Institutionnelle de l'Ifremer

The original publication is available at http://www.tandf.co.uk/journals/

\title{
A new deep-sea genus of Nannastacidae (Crustacea, Cumacea) from the Lucky Strike hydrothermal vent field (Azores Triple Junction, Mid- Atlantic Ridge)
}

\author{
Jordi Corbera ${ }^{\mathrm{a},{ }^{*}}$, Michel Segonzac $^{\mathrm{b}}$, Marina R. Cunha ${ }^{\mathrm{c}}$
}

\author{
${ }^{\text {a }}$ Argentona, Catalonia, Spain \\ ${ }^{\mathrm{b}}$ Ifremer, Centre de Brest, Plouzané, France \\ ${ }^{c}$ CESAM, Departamento de Biologia, Universidade de Aveiro, Aveiro, Portugal \\ *: Corresponding author : Corbera J., email address : corbera@sct.ictnet.es
}

\begin{abstract}
:
A new cumacean genus and species, Thalycrocuma sarradini gen. et sp. nov., belonging to the family Nannastacidae is described from several sites of the Lucky Strike hydrothermal vent field (Mid-Atlantic Ridge, $37^{\circ} \mathrm{N}, 1700 \mathrm{~m}$ depth). The new genus differs from others in the family by males lacking exopods on the pereopods 3 and 4 and having an antenna with a five-articulate peduncle and a short flagellum. This is the first cumacean species that could be considered, at the moment, as endemic from hydrothermal vent areas. Data on the accompanying fauna including other cumacean species (Cyclaspis longicaudata, Bathycuma brevirostre, Procampylaspis sp. and Makrokylindrus sp.) and some ecological remarks are included. A key for the currently known genera of the family Nannastacidae is provided and the taxonomic position of some genera is discussed.
\end{abstract}

Keywords: Cumacea; deep sea; hydrothermal vents; Mid-Atlantic Ridge; morphology; systematics

\section{Introduction}

Since the discovery in 1977 of hydrothermal vents as a new deep-sea ecosystem and its associated fauna (Weiss et al. 1977; Lonsdale 1977), more than 700 species are recorded living in this environment (Wolff 2005; Desbruyères et al. 2006). Although, this is not a high number, most species are endemic from this habitat (71\%) while only a 
few (5\%) are shared with other reduced marine environments, i.e. cold seeps and whale falls (Wolff 2005). Mollusca and Crustacea are the taxa showing the highest diversity. Among crustaceans, copepods and decapods are the most speciose (Heptner and Ivanenko 2002; Martin and Haney 2005).

Among the peracarid crustaceans, the amphipods are the best represented ( 24 species; Bellan-Santini 2006), while tanaids and isopods are less frequently identified (Cunha 2006; Cunha and Wilson 2006; Larsen et al. 2006).

Similarly, very little is known on the cumacean fauna of chemosynthetic-based marine ecosystems. Only two cumacean species, Atlantocuma bidentatum Ledoyer 1988 and Bathycuma brevirostre (Norman 1879), have been recorded from hydrothermal vent vicinity (Corbera 2006) while four other (Diastylopsis dawsoni Smith 1880, Eudorella pacifica Hart 1930, Campylaspis sp. and ?Hemilamprops sp.) were found in north Californian methane seeps (Levin et al. 2000, 2003). This is perhaps due to a lack of sampling, but probably also to a poor representation of this group in these environments.

The family Nannastacidae currently comprises 28 genera. Few of them had been assigned to distinct families by some authors. Genus Picrocuma was described firstly in the family Bodotriidae (Hale 1936) but, because of the lack of pleopods in the male and the shape of the mandible, the same author (Hale 1945) transferred it to the Nannastacidae when these characteristics were described for the male of the type species. Several years later, Bacescu (1988) considered it again as a member of the Bodotriidae, a criterion also followed by Tafe and Greenwood (1996) and MühlenhardtSiegel (2003). A similar trajectory has followed the genus Atlantocuma. First described within the Bodotriidae (Bacescu and Muradian 1974), it was assigned to this family by Bacescu (1988) and Corbera (2006) but to the family Nannastacidae by Jones (1984) and Ledoyer (1988, 1993). A phylogenetic analysis made by Haye (2002) on 86 parsimony-informative morphological characters grouped Atlantocuma and Picrocuma external to all bodotriid genera. Although these genera have a doubtful position, they are here provisionally included in the family Nannastacidae. Further studies on the genera and families of Cumacea with pleotelson are needed to solve the position of genera in question.

On the other hand, genera Schizocuma Bacescu 1972 and Styloptocuma Bacescu and Muradian 1974 were not recognized by Jones (1984), while Watling (1991) accepted Schizocuma but considered Styloptocuma a subgenus of Cumella Sars 1865. Later on, a 
detailed morphological study led Petrescu (2000a) to consider again Styloptocuma as valid genus.

Material collected in the Lucky Strike hydrothermal vent field belongs to a new species that cannot be included in any of the currently known genera. The new species is described in this paper and data on the ecological parameters of its habitat are provided.

\section{Material and methods}

The specimens were collected on the Mid-Atlantic Ridge (MAR) in the Lucky Strike hydrothermal vent field, at different sites and by different means. At the Eiffel Tower site, cumaceans were collected by two in situ colonization experiment gears called SMAC, B and C (Small Module Autonome de Colonisation). Each of the arrays consisted of four trays containing artificial sediment (dust-size glass beads) and different organic materials and concentrations to attract opportunistic animals. These arrays were moored during MARVEL cruise (N/O L'Atalante, submersible Nautile, dives 1194 and 1195, 20-21.08.1997), at the base of the chimney, which is covered with the mytilid bivalves Bathymodiolus azoricus Cosel and Comtet in Cosel, Comtet and Krylova 1999. The SMACs were recovered 320 days later during the PICO cruise (N/O Nadir, submersible Nautile, dives 1268 and 1269, 05-06.07.1998). At the vent site Sintra, specimens were collected by a sediment trap, moored during the ATOS cruise (N/O L'Atalante) and deployed by the ROV Victor 6000, between two active chimneys, $30 \mathrm{~m}$ apart. The sediment trap provides information about the export and the distribution of hydrothermal particle material to the surrounding deep ocean. It allows also a sequential collection - each two weeks - of a diversified fauna composed of invertebrate larvae and other small animals (see Khripounoff et al. 2001 for its mode of use). The mouth of the trap is situated $2.5 \mathrm{~m}$ above the bottom. Trap was recovered a year later (3.07.2002) by the R/V Arquipélago (IMAR, Portugal). Further samples were collected during the cruises TTR10 (August 2000) and TTR12 (August 2002) onboard the RV Prof. Logatchev (Training Through Research programme, IOC-UNESCO). The location of samples inside the vent field was predetermined and based on data (ROV Jason images) obtained during the cruise LUSTRE-1996. A TV-guided grab was used 
to locate different types of rocks allowing a minimally destructive sampling procedure. Macroinvertebrates were picked from the surface of the rocks or sorted from sieved sediments and rock washings. Samples were preserved in $70 \%$ ethanol. Data on the stations yielding cumaceans are presented in Table 1.

For morphological observations, the cumaceans were dissected in lactic acid and stained with chlorazol black. Material preserved as permanent glass slides was mounted in Fauré medium and sealed with nail varnish. Drawings were prepared after dissection in lactic acid (except for the whole animal and the uropod) using a camera lucida on an Olympus microscope. A few specimens were examined with a Hitachi H-2300 Scanning Electron Microscope; they were prepared by dehydration through graded ethanol, critical point dried, mounted on stubs and sputter-coated with gold. Material was deposited in the Muséum National d'Histoire Naturelle, Paris (MNHN), in the Biological Research Collection of the Department of Biology, University of Aveiro (DBUA) and in the Cumacean collection of the Institut de Ciències del Mar, Barcelona (ICMU).

\section{Systematics}

Order Cumacea Kröyer 1846

Family Nannastacidae Bate 1866

Genus Thalycrocuma gen. nov.

Diagnosis. Carapace anterolateral angle acute but not projecting, eyelobe single, branchial siphons slightly separated in males and preadult females, meeting in front of eyelobe in adult females. Mandible molar process truncate. Antennula article 2 without process, article 3 of males with two sets of sensory setae. Antenna of male developed with a short flagellum not exceeding carapace length. Maxilliped 3 and pereopods 1 and 2 with exopods in both sexes. Uropod peduncle longer than pleonite 6; uropod exopod longer than its terminal seta, basal article short; endopod 1-articulate.

Etymology. From the Greek thalykros meaning hot, referring to the increase in water 
temperature due to vent activity in the environment where type species was collected.

Type species. Thalycrocuma sarradini sp. nov.

Remarks. Although in most of the genera of the family Nannastacidae males have five pairs of exopods (on maxilliped 3 and pereopods 1-4) there are few with a lower number. Males of Picrocuma Hale 1936, Cubanocuma Bacescu and Muradian 1977 and Claudicuma Roccatagliata 1981 have no exopod on pereopod 4, while those of Almyracuma Jones and Burbanck 1959 have not exopods beyond pereopod 2. Thalycrocuma gen. nov. resembles Almyracuma by the number of exopods and Picrocuma by the shape and length of antenna of male but neither has the combination of both characters. Moreover males and preadult females of Thalycrocuma have the branchial siphons slightly separated. The monotypic genus Elassocumella Watling 1991 is only known by a single adult female that has not exopods. It is possible that males of this genus could also have a reduced number of exopods, but Elassocumella also differs from the genus described above by the shortness of its uropods.

Finally, the presence of sensory setae on the peduncle of antennula is a case unique between the nannastacid males. Although males of some genera of other cumacean families have sensory setae on the antennula, they are located in most of the cases on the main flagellum.

Thalycrocuma sarradini sp. nov. (Figures 1-6)

Type material. North Atlantic Ocean, Mid-Atlantic Ridge, Azores Triple Junction, Lucky Strike vent area. Holotype: ATOS cruise, sediment trap ML3-19 (2.5 m above the bottom), site Sintra, $37^{\circ} 17.539^{`} \mathrm{~N}, 32^{\circ} 16.404^{`} \mathrm{~W}, 1630 \mathrm{~m}, 3.07 .2002$, adult female (MNHN Cu-1103). Allotype: TTR10 cruise, stn AT271Gr, TV-grab, 37²17.461'N, $32^{\circ} 16.924^{\prime} \mathrm{W}, 1712 \mathrm{~m}, 4.08 .2000$, adult male dissected in one slide (MNHN Cu-1104). Paratypes: same station as holotype, one preadult female dissected in two slides (MNHN Cu-1105); stn ML3-18, one manca (MNHN Cu-1106); PICO cruise, sample number SMAC C-6, 37 $17.357^{`} \mathrm{~N}, 32^{\circ} 16.479^{`} \mathrm{~W}, 1705 \mathrm{~m}, 6.07 .1998$, two juveniles (MNHN Cu-1107); SMAC B-9, 37²17.358`N, 32¹6.511`W, 1690 m, 5.07.1998, one juvenile (MNHN Cu-1108); same station as allotype, four adult females, 15 preadult females, 13 males (DBUA-00874.05) three additional males were used for SEM study; 


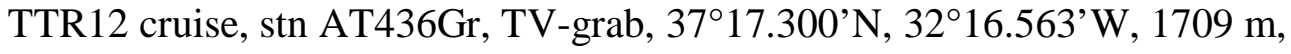
29.08.2002, three adult females, three preadult females, 6 males (ICMU 60/2007) and 6 males (MNHN Cu-1109).

Other material. Location close to the holotype. TTR10 cruise, stn AT250Gr, TV-grab, $37^{\circ} 17.275^{\prime} \mathrm{N}, 32^{\circ} 16.525^{\prime} \mathrm{W}, 1704 \mathrm{~m}, 1.08 .2000$, two adult females, two preadult females, two males (DBUA-00874.01); TTR10, stn AT251Gr, TV-grab, 37¹7.356’N, $32^{\circ} 16.657^{\prime} \mathrm{W}, 1685 \mathrm{~m}, 1.08 .2000$, one preadult female (DBUA-00874.02); TTR10, stn AT255Gr, TV-grab, 37017.503’ N, 32 $16.610^{\prime} \mathrm{W}, 1680 \mathrm{~m}, 2.08 .2000$, one male (DBUA00874.03); TTR10, stn AT279Gr, TV-grab, 37²17.400’’ $, 32^{\circ} 16.625^{\prime} \mathrm{W}, 1703 \mathrm{~m}$, 5.08.2000, two adult females (one of them used for SEM study), one male (DBUA00874.04); TTR12, stn AT428Gr, 37²17.289’ N, 32¹6.522’ W, 1716 m, 26.08.2002, one adult female, one male (DBUA-00875.01).

Etymology. The species is named in honour of Pierre-Marie Sarradin (Ifremer, Brest) for his valuable accomplishments in the study of the environmental conditions of hydrothermal vent communities.

Diagnosis. Carapace covered by small spines and with 2-3 teeth on mid-dorsal line. Eyelobe rounded, not reaching the end of pseudorostrum. Antero-lateral angle acute, lower margin serrate. Pleonites 3-5 with five longitudinal rows of spines, pleonite 6 with three. Uropod peduncle longer than endopod, with serrate outer margin and a dorsal row of spines.

Description. Adult female $2.43 \mathrm{~mm}$ total length. Carapace (Figure 1A) more than $1 / 3$ of total length fully covered by small spines directed forwardly (Figure 4A) (sometimes difficult to see when it is covered by sediment) and two teeth on mid-dorsal line; eyelobe rounded not reaching the tip of pseudorostrum, without optical lenses; pseudorostral lobes meeting in front eyelobe (slightly separated in preadult females); anterolateral angle acute, lower margin serrate. Pleonites 3-5 with longitudinal rows of spines (Figure 4B); pleonite 6 with three rows (spines were not visible on free pereonites and proximal pleonites because the thin sediment layer covering the animal). Antennula (Figure 1B), peduncle 3-articulate; article 1 longer than article 3; article 2 shorter than article 3; main flagellum 2-articulate, with two aesthetascs and two long 
simple setae; accessory flagellum rudimentary. Left mandible (Figure 1C) with three teeth on the pars incisiva, five setae between pars incisiva and truncated pars molaris (six setae on right mandible; Figure 1D). Maxillula (Figure 1E) palp with two unequal filaments, inner endite with four setae, two simple, one trifid and one serrulate. Maxilla endites exceeding the protopod, with simple and serrulate setae.

Maxilliped 1 (Figure 1F) basis with four plumo-serrate and two simple setae on inner margin, distally produced reaching carpus; carpus with four flattened hand-like-side setae on the inner margin; propodus with three setae on distal inner corner. Maxilliped 2 (Figure 2A) basis shorter than rest of appendage, with a long plumose seta on distal inner corner; merus with a long plumose seta on distal inner corner; carpus shorter than merus with simple seta on inner margin; propodus shorter than carpus, with simple seta on inner margin and two plumose setae distally. Maxilliped 3 (Figure 2B) with well developed exopod, basis as long as rest of appendage, not expanded distally, with three long plumose setae on distal outer corner and two pappose setae on inner margin; merus with a plumose seta on inner margin; carpus longer than merus, with a plumose and a simple setae on inner margin and a long plumose seta on distal outer corner; propodus longer than carpus with two setae on inner margin; dactylus half length of propodus. Pereopod 1 (Figure 2C) with well developed exopod, basis shorter than the rest of appendage, with two simple and one plumose setae distally; merus longer than ischium; carpus twice as long as merus with simple setae on both margins; propodus shorter than carpus and longer than dactylus. Pereopod 2 (Figure 2D) with well developed exopod, basis shorter than rest of appendage, with a small plumose seta on distal lower corner, upper margin serrate with a plumose seta near the distal margin; ischium very short with a plumose seta on distal lower corner; merus shorter than carpus; carpus with two cuspidate setae on distal lower corner; propodus half length of merus with a seta on distal corner; dactylus more than two times as long as propodus, with a simple seta on lower margin, one on upper margin and four terminally (the longest longer than article). Pereopod 3 (Figure 3A) basis longer than rest of appendage, anterior margin serrate, with simple setae on anterior margin and a plumose seta on distal corner; ischium with two simple setae on distal corner; merus with two simple seta on the margin; carpus twice as long as merus, with a long simple setae on distal corner; propodus shorter than half length of carpus, with a long simple seta on distal corner. Pereopod 4 (Figure 3B) basis as long as rest of appendage with simple and articulate setae; merus with a simple seta on distal corner; carpus three times as long as merus, with a simple seta on distal 
corner; propodus shorter than half length of carpus, with a long simple seta on distal corner. Pereopod 5 (Figure 3C), basis shorter than rest of appendage; carpus three times as long as propodus with a long simple seta on distal corner; propodus shorter than merus, with a long simple seta on distal corner.

Uropod peduncle (Figure 3D) longer than pleonite 5 and 1.5 times as long as endopod, outer margin serrate and with a dorsal row of spines; endopod 1-articulate with outer margin serrate on its proximal 2/3, 6 acuminate setae on inner margin and 4 terminally; exopod 2-articulate, shorter than endopod, with two long simple setae terminally.

Adult male $2.05 \mathrm{~mm}$ total length, carapace fully covered by small directed forwardly spines (Figure 4C, D) branchial siphons longer than in adult female and slightly separate (Figure 5A). Antennula (Figures 4E, F, 5B), peduncle 3-articulate; article 1 slightly longer than article 3; article 2 nearly as long as article 3; article 3 with two sets of sensory setae on ventral face and several more on distal margin; main flagellum 2articulate, with two aesthetascs and two long simple setae; accessory flagellum rudimentary. Antenna (Figure 5C) not exceeding length of carapace; peduncle 5articulate, article 5 the longest with three long sensory setae near the distal margin; flagellum 6-articulate shorter than peduncle. Mouth appendages as in female.

Maxilliped 3 and pereopods 1 (Figure 5D) and 2 (Figure 6A) with well developed exopods. Pereopods 3-5 (Figures 6B-D) and uropods of the same proportions and ornamentation than in female.

Remarks. Although male of Thalycrocuma sarradini sp. nov. is easily identifiable by the number of exopods and the shape of antenna (see remarks on the genus above), female resembles Cumella hystrix Gamô 1997, and Cumella spinifera Petrescu and Heard 2004b by having the carapace covered with small spines. Cumella hystrix is twice larger than T. sarradini (4.6 vs $2.4 \mathrm{~mm}$ of total length, measured in adult females) and its uropod peduncles are not strongly serrate. Moreover, it actually has an elongate eyelobe, a character that places it within the genus Styloptocuma, thus we hereby formally transfer Cumella hystrix Gamô 1997 to Styloptocuma Bacescu and Muradian 1974 to become Styloptocuma hystrix (Gamô 1997), new combination.

Cumella spinifera, a shallow-water species, also has its carapace covered by small spines, but the pleon somites have no spines and its uropod peduncle is smooth. 


\section{Key to the genera of the family Nannastacidae}

Based in part on the key published by Bacescu and Muradian (1977) a new one is here proposed including the new genera described since then:

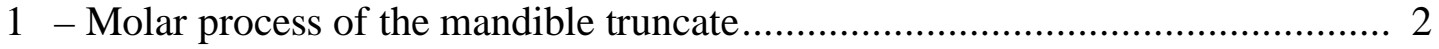

- Molar process of the mandible styliform ................................................... 19

2 - Ocular elements separate in two groups ….............................................. 3

- Ocular elements fused in a single median lobe or absent ........................... 5

3 - Branchial siphons separate ....................................... Schizotrema Calman 1911

- Branchial siphons united medially ............................................................ 4

4 - Anteroventral corner large, acute and strongly projecting, pseudorostral lobes short, directed slightly upward Nannastacus Bate 1865

- Anteroventral corner in female acute or subacute, not projecting, pseudorostral lobes elongate, united in front of head Scherocumella Watling 1991

5 - Female without exopods 6

- Female with at least 2 pairs of exopods 7

6 - Eyelobe rounded not reaching the tip of pseudorostrum, peduncle of uropods shorter than pleonite 6 Elassocumella Watling 1991

- Eyelobe narrow, elongate, reaching the tip of pseudorostrum, peduncle of uropods longer than pleonite 6 Styloptocumoides Petrescu 2006

7 - Antenna rudimentary in males as in females 8

- Antenna of males with a flagellum more or less long

8 - Three pairs of exopods in both sexes...... Almyracuma Jones and Burbanck 1959

- Male with four pairs of exopods. Claudicuma Roccatagliata 1981 
9 - Antenna of male with a short flagellum not exceeding posterior margin of carapace

- Antenna of male with a long flagellum exceeding the posterior margin of carapace

10 - Antenna of male with flagellum shorter than peduncle

- Antenna of male with flagellum shorter than peduncle

11 - Both sexes with four pairs of exopods Picrocuma Hale 1936

- Both sexes with three pairs of exopods. Thalycrocuma gen. nov.

12 - Females with two pairs of exopods .... Atlantocuma Bacescu and Muradian 1974

- Females with three pairs of exopods

13 - Gut spirally coiled Platycuma Calman 1905

- Gut not coiled Cumellopsis Calman 1905

14 - Eyelobe narrow, elongate, reaching the end of pseudorostral lobes Styloptocuma Bacescu and Muradian 1974

- Eyelobe rounded with or without lenses 15

15 - Branchial siphons separate Schizocuma Bacescu 1972

- Branchial siphons united medially 16

16 - Pars incisiva of mandible with four teeth, peduncle of antennula article 2 with a tubercle Vemacumella Petrescu 2001

- Pars incisiva of mandible with three teeth, peduncle of antennula without tubercle

17 - Peduncle of uropod shorter than pleonite 6 18

- Peduncle of uropod as long as or longer than pleonite 6 Cumella Sars 1865 
18 - Pereopod 2 without ischium Humesiana Watling and Gerken 2001

- Pereopod 2 with iscium Bacescella Petrescu 2000b

19 - Females without exopods Normjonesia Petrescu and Heard 2001

- Females with at least three pairs of exopods (on maxilliped 3 and pereopods 1 and 2) 20

20 - Females with rudimentary exopods on pereopods 3 and 4 . 21

- Females with only three pairs of exopods 22

21 - Basis of maxilliped 2 with a peculiar club-shaped organ.

Floridocuma Bacescu and Muradian 1974

- Basis of maxilliped 2 without this organ, dactyl of pereopod 2 club-shaped

Bathycampylaspis Mühlenhardt-Siegel 1996

22 - Dactylus of maxilliped 2 with long spines or teeth 23

- Dactylus of maxilliped 2 short, ending in two or more spines

23 - Dactylus of maxilliped 2 in from of a trident Campylaspides Fage 1929

- Dactylus of maxilliped 2 shaped like a rake Procampylaspis Bonnier 1896

24 - Males with four pairs of exopods Cubanocuma Bacesu and Muradian 1977

- Males with five pairs of exopods. 25

25 - Male with a very large and well developed penis on last pereonite.

Campylaspenis Bacesu and Muradian 1974

- Male without a well developed penis 26

26 - Pseudorostral lobes not meeting in front of head Pavlovskeola Lomakina 1955

- Pseudorostral lobes meeting in front of head 27

27 - Carpus of maxilliped 3 expanded laterally, anterolateral angle well produced Paracampylaspis Jones 1984

- Carpus of maxilliped 3 not expanded Campylaspis Sars 1865 


\section{Taxonomical affinities}

As commented above, the new genus described here shows its higher affinities with Almyracuma, Claudicuma and Picrocuma. All the species of these three nannastacid genera live in shallow-water. The two known species of the genus Almyracuma inhabit brackish and freshwater habitats of the south coast of the United States and some specimens were collected $100 \mathrm{~km}$ upstream (Petrescu and Heard 2004a). Claudicuma, a monotypic genus, has been recorded on the Argentine shore of Rio de la Plata, from Buenos Aires to Punta Indio, about $150 \mathrm{~km}$ downstream, where salinity range from 0.5 to 7 (Roccatagliata 1991). Finally, the three species of Picrocuma are known from Australian coasts where are common in sandy bottoms and rocky reef up to $4 \mathrm{~m}$ depth (Tafe and Greenwood 1996; Mühlenhardt-Siegel 2003). It is difficult to understand how the deep-water genus described above have such morphological affinities with littoral genera. However, similar affinities with shallow-water fauna have been pointed out for deep-sea hydrothermal vents and cold-water seeps bathymodiolid mussels (Craddock et al. 1995; Distel et al. 2000) and polychaete worms in the genera Ophryotrocha and Amphisamytha (Van Dover 2000). It seems to be clear that reduction in the number of exopods is a character that could have evolved independently by different ways (it may be observed also in other cumacean families) and within the Nannastacidae it could be associated to the life in stressed environments.

\section{Ecological remarks}

The SMACs, where part of the material studied were collected, had been placed on a mussel bed close to an active chimney. In such mussel assemblages, the temperature ranges generally between 5 and $15^{\circ} \mathrm{C}$ but can even reach $25^{\circ} \mathrm{C}$ (Sarradin et al. 1999). Alvinocaridid shrimps, bythograeid crabs and galatheid crabs live on this mussel bed (Desbruyères et al. 2001). The trays of SMACs containing cumaceans were composed of artificial sediment not enriched by organic matter. It contained 323 invertebrates including (in order of decreasing abundance): Polychaeta, Copepoda (4 families of which Tisbidae having species known for their strong preference for the hydrothermal 
conditions; V. Ivanenko, unpublished data), vent gastropods Lurifax vitreus Warén and Bouchet 2001 and Protolira thorvaldssoni Warén 1996 (A. Warén, unpublished data), post-larvae of mytilid bivalves and Ostracoda.

The holotype and two paratypes were collected in a sediment trap with a male of Bathycuma brevirostre, a moult of Makrokylindrus sp. and the vent gastropods

Protolira thorvaldssoni. These hydrothermal vent gastropods, as well as the cumaceans, are benthic. It is thus surprising to find them in trap whose opening is located at $2.5 \mathrm{~m}$ of the bottom. As noticied by Khripounoff et al. (in press) it is suggested that the hydrodynamic turbulence occurring around the active black smokers, could cause resuspension of the hydrothermal sediment and the small-sized animals.

The material obtained during the TTR cruises was collected inside the vent field, mostly in the SE area, close to Tour Eiffel, Y3 and Chimiste vents (see Desbruyères et al. 2001) but also from the NW area (close to Nuno vent), and from different geological settings: sulphides from areas of active diffuse venting (AT271Gr), sulphides and sulphide rubble from more peripheral areas (AT251Gr, AT255Gr) where a specimen of Procampylaspis sp. was also collected (AT248Gr), hydrothermal slabs near active venting (AT428Gr and AT436Gr), and volcanic basalts (AT250Gr, AT279Gr). Higher abundances were recorded in the vicinity of active areas (AT271Gr, 40 individuals; AT436Gr, 21 individuals) together with more than 30 other species of macroinvertebrates, including typical vent polychaetes (Amathys lutzi Desbruyères and Laubier 1996 and other Ampharetidae, Polynoidae and several other families) and molluscs but mainly small peracarid crustaceans such as several species of tanaids (Larsen et al. 2006), the abundant Bonnierella compar (Myers and Cunha 2004) and other amphipods, and different isopod species. Thalycrocuma sarradini appears to be a common and rather abundant species in Lucky Strike; it was retrieved from eight out of 29 grab samples collected inside the vent field but in none of the five grab samples collected in the Lucky Strike segment outside the vent field. The ochre colour of the studied cumaceans is caused by oxide-sulphide deposits, which indicate a hydrothermal way of life. Thus we believe that Thalycrocuma sarradini is the first species of Cumacea endemic of the hydrothermal areas. An effort of macrofauna sampling of the hydrothermal sediments will be needed to confirm this idea.

Sets of sensory setae on the male antennula are a rare feature within the Nannastacidae. Similar receptors were described from the antennae of the vent shrimps Rimicaris and their chemical sensitivity was demonstrated (Renninger et al. 1995). These shrimps 
have a positive response to sulphides. However, the presence of this kind of sensory receptors only in adult males could be associated alternatively to the search of the female for reproductive purpose. Physiological studies, which are very scarce in the cumacean literature, will be useful to know the function of such sensory structures.

\section{Acknowledgements}

We thanks the Chief scientists Pierre-Marie Sarradin (ATOS, Ifremer), Daniel Desbruyères (PICO, Ifremer), Ana Colaço (Arquipélago, IMAR, Portugal) and Mikhail Ivanov (TTR10 and TTR12, Moscow State University, Russia) and José Hipólito Monteiro, (TTR10 and TTR12, INETI, Portugal); Alexis Khripounoff (Ifremer), responsible of the sediment trap; as well as the Captains and crew of the R/Vs L'Atalante, Nadir, Arquipélago and Prof. Logatchev, and the pilots of the submersibles Nautile and ROV Victor 6000. This work was partly funded through the MAST 3, AMORES (MAS3-CT95-0040) and VENTOX European projects (EVK3-1999-00003).

R. Fontarnau and collaborators are also thanked for their assistance during SEM sessions in the Serveis Cientificotècnics (University of Barcelona).

\section{References}

Bacescu M. 1972. Archaeocuma and Schizocuma, new genera of Cumacea from the American tropical waters. Revue Roumaine de Biologie, serie Zoologie 17:241-245

Bacescu M. 1988. Cumacea I (Fam. Archaeocumatidae, Lampropidae, Bodotriidae, Leuconidae). In Gruner H-E, Holthuis LB (eds): Crustaceorum Catalogus Pars 7. The Hague: SPB Academic Publishing, p 173.

Bacescu M, Muradian Z. 1974. Campylaspenis, Styloptocuma, Atlantocuma, new genera of Cumacea from the deep waters of the Atlantic. Revue Roumaine de Biologie, série Biologie Animale 19(2):71-78.

Bacescu M, Muradian Z. 1977. Cubanocuma gutzui gen. et sp. n. (Cumacea, Nannastacidae) from the tropical western Atlantic. Revue Roumaine de Biologie, Biologie Animale 22(1):3-9.

Bate S. 1865. XI.- Carcinological gleanings.- No. I. Annals and Magazine of Natural History Ser. 3 15(86):81-88, 
Bellan-Santini D. 2006. Arthropoda, Crustacea, Amphipoda. In: Desbruyères D, Segonzac M, Bright M editors, Handbook of Deep-Sea Hydrothermal Vent Fauna. 2nd. ed. Denisia 18:382.

Bonnier JJ. 1896. Édriophthalmes. Résultats Scientifiques de la Campagne du "Caudan" dans le Golfe de Goscogne, Août-Septembre 1895. Annales de l'Université de Lyon 26(3):528-562

Calman WT. 1905. The marine fauna of the west coast of Ireland, Part IV. Cumacea. Fisheries Ireland Scientific Investigations, 1904, I, 1905:1-52

Calman WT. 1911. IV. On new or rare Crustacea of the order Cumacea from the collection of the Copenhagen Museum. Part II. The families Nannastacidæ and Diastylidæ. Transactions of the Zoological Society of London 18(1):341-398

Corbera J. 2006. Arthropoda, Crustacea, Cumacea. In: Desbruyères D, Segonzac M, Bright M, editors. Handbook of Deep-Sea Hydrothermal Vent Fauna. 2nd ed. Denisia 18:370-1.

Cosel R von, Comtet T, Krylova EM. 1999. Bathymodiolus (Bivalvia: Mytilidae) from hydrothermal vents on the Azores Triple Junction and the Logatchev hydrothermal field, Mid-Atlantic Ridg. The Veliger 42(3):218-248.

Craddock C, Hoeh WR, Gustafson RG, Lutz RA, Hashimoto J, Vrijenhoek RJ. 1995. Evolutionary relationships among deep-sea mytilids (Bivalvia: Mytilidae) from hydrothermal vents and cold-water methane/sulfide seeps. Marine Biology 121:477485

Cunha MR. 2006. Arthropoda, Crustacea, Isopoda. In: Desbruyères D, Segonzac M, Bright M, editors. Handbook of Deep-Sea Hydrothermal Vent Fauna. 2nd ed. Denisia 18:379.

Cunha MR, Wilson GDF. 2006. The North Atlantic genus Heteromesus (Crustacea: Isopoda: Asellota: Ischnomesidae). Zootaxa 1192:1-76.

Desbruyères D, Laubier L. 1996. A new genus and species of ampharetid polychaete from deep-sea hydrothermal vent community in the Azores triple-junction area. Proceedings of the Biological Society of Washington 109(2):248-255.

Desbruyères D, Biscoito M, Caprais J, Colaco A, Comtet T, Crassous P, Fouquet Y, Khripounoff A, Le Bris N, Olu K, Riso R, Sarradin P-M, Segonzac M, Vangriesheim A. 2001. Variations in deep-sea hydrothermal vent communities on the Mid-Atlantic Ridge near the Azores plateau. Deep-Sea Research I 48:1325-1346. 
Desbruyères D, Segonzac M, Bright M, editors. 2006. Handbook of Deep-Sea Hydrothermal Vent Fauna, 2nd ed. Denisia 18:1-544.

Distel DL, Baco AR, Chuang E, Morrill W, Cavanaugh C, Smith CR. 2000. Do mussels take wooden steps to deep-sea vents? Nature 403(6771):725-726.

Fage L. 1929. Cumacés et Leptostracés provenant des Campagnes du Prince Albert 1er de Monaco. Résultats des Campagnes Scientifiques Accomplies sur son Yacht par Albert 1er Prince Souverain de Monaco 77: 3-51.

Gamô S. 1997. A new cumacean crustacean, Cumella hystrix (Nannastacidae) from the bathyal depth in Suruga Bay. Bulletin of the National Science Museum Tokyo ser A 23(4):177-184.

Hale HM. 1936. Cumacea from a South Australian reef. Records of the South Australian Museum 5(4):404-438.

Hale HM. 1945. Australian Cumacea. No. 9. The family Nannastacidae. Records of the South Australian Museum 8(2):145-218.

Hart JFL. 1930. Cumacea and Decapoda of the western Canadian Arctic region, 19361937. Canadian Journal of Research 17:62-67.

Haye P. (2002). Systematics of the Cumacea (Crustacea). PhD Thesis, University of Maine.

Heptner M, Ivanenko V. 2002. Copepoda (Crustacea) of hydrothermal ecosystems of the World Ocean. Arthropoda Selecta 12(2):117-134.

Jones NS. 1984. The family Nannastacidae (Crustacea: Cumacea) from deep Atlantic. Bulletin of the British Museum (Natural History) 46:207-289.

Jones NS, Burbanck WD. 1959. Almyracuma proximoculi gen. et sp. nov. (Crustacea, Cumacea) from brackish water of Cape Cod, Massachusetts. Biological Bulletin 116(1):115-124.

Khripounoff A, Vangriesheim A, Crassous P, Segonzac M, Colaço A, Desbruyères D, Barthélémy R. 2001. Particle flux in the Rainbow hydrothermal vent field (MidAtlantic Ridge): Dynamics, mineral and biological composition. Journal of Marine Research 59:633-656.

Khripounoff A, Vangriesheim A, Crassous P, Segonzac M, Lafon V. Temporal variation of current, particulate flux and larvae supply at two deep-sea hydrothermal fields (Rainbow and Lucky Stricke) of the Azores Triple Junction (ATJ). Deep-Sea Research I, in press. 
Larsen K, Blazewicz-Paszkowycz M, Cunha MR. 2006. Tanaidacean (Crustacea:

Peracarida) fauna from chemically reduced habitats - the Lucky Strike hydrothermal vent system, Mid-Atlantic Ridge. Zootaxa 1187:1-36

Ledoyer M. 1988. Cumacés (Crustacea) profonds de la région de l'Ile de Mayotte, Canal de Mozambique, Océan Indien (Campagne Benthedi, 1977). Mesogée 48:131172.

Ledoyer M. 1993. Cumacea (Crustacea) de la campagne EPOS 3 du R.V. Polarstern en mer de Weddell, Artarctique. Journal of Natural History 27:1041-1096.

Levin L, James D, Martin C, Rathburn A, Harris L, Michener R. 2000. Do methane seeps support distinct macrofaunal assemblages? Observations on community structure and nutrition from the northern California slope and shelf. Marine Ecology Progress Series 208:21-39.

Levin L, Ziebis W, Mendoza G, Growney V, Tryon M, Brown K, Mahn C, Gieskes J, Rathburn A. 2003. Spatial heterogeneity of macrofauna at northern California methane seeps: Influence of sulfide concentration and fluid flow. Marine Ecology Progress Series 256:123-139.

Lomakina M. 1955. Pavlovskeola campylaspoides-predstavitel novogo roda kumovih rakov (Cumacea: Nannastacidae). Trudy Zoologicheskogo Instituta 21:190-192.

Lonsdale P. 1977. Clustering of suspension-feeding macrobenthos near abyssal hydrothermal vents at oceanic spreading centers. Deep-Sea Research, 24:857-863.

Martin J, Haney T. 2005. Decapod crustaceans from hydrothermal vents and cold seeps: a review through 2005. Zoological Journal of the Linnean Society 145(4):445-522.

Mühlenhardt-Siegel U. 1996. Cumacea (Crustacea) from the Red Sea and the Maldives (Indian Ocean) in the collection of the Zoological Museum, Hamburg, with the description of seven new species and a new genus. Beaufortia 46(7):105-134.

Mühlenhardt-Siegel U. 2003. Shallow-water cumacean Crustacea from Australia and Lombok (Indonesia): families Bodotriidae and Leuconidae. Records of the South Australian Museum 36(1):21-57.

Myers AA, Cunha MR. 2004. New and little known corophiidean amphipods from the 'Lucky Strike' hydrothermal vent, Mid-Atlantic Ridge. Journal of the Marine Biological Association of the United Kingdom, 84(5):1019-1025.

Norman AM. 1879. Crustacea Cumacea of the 'Lightning', 'Porcupine' and 'Valorous' expeditions. Annals and Magazine of Natural History 5:54-73.

Petrescu I. 2000a. Remarks on the genera Schizocuma Bacescu, 1972 and Styloptocuma 
Bacesu \& Muradian, 1974 (Crustacea, Cumacea). Bulletin of the Natural History Museum of London (Zoology) 66(2):147-166.

Petrescu I. 2000b. Cumacea Crustacea collected from Tanzanian coasts by the "Grigore Antipa” Museum of natural History (Romania). Part III. genera Cumella Sars, 1865 and Bacescella n. gen. Beaufortia 50(6):127-138.

Petrescu I. 2001. New deep-sea Nannastacidae (Crustacea, Cumacea) from the Eastern Pacific collected by R.V. "Vema". Journal of Natural History 35(11):1657-1680.

Petrescu I. 2006. Nannastacidae (Crustacea: Cumacea) from eastern Bass Strait, the south-eastern Australian slope, and Antarctica in the collections of Museum Victoria. Memoirs of Museum Victoria 63(2):129-173.

Petrescu I, Heard RW. 2001. Normjonesia danieli, a new genus and species of nannastacid cumacean (Malacostraca: Peracarida) from the southwest Florida continental shelf. Journal of Crustacean Biology 21:469-474.

Petrescu I, Heard RW. 2004a. Redescription of Almyracuma proximoculi Jones \& Burbanck, 1959 (Crustacea: Cumacea: Nannastacidae ) and description of a new species, A. bacescui n. sp., from the Gulf of Mexico. Travaux du Muséum National d'Histoire Naturelle "Grigore Antipa" 47:97-109.

Petrescu I, Heard RW. 2004b. Three new species of Cumacea (Crustacea: Peracarida) from Costa Rica. Zootaxa 721:1-12.

Renninger G, Kass L, Gleeson R, Dover C, Battelle B, Jinks R, Herzog E, Chamberlain S. 1995. Sulfide as a chemical stimulus for deep-sea hydrothermal vent shrimp. Biological Bulletin 189(2):69-76.

Roccatagliata D. 1981. Claudicuma platensis gen. et sp. nov. (Crustacea, Cumacea) de la Ribera Argentina del Río de la Plata. Physis 79:79-87.

Roccatagliata D. 1991. Claudicuma platensis Roccatagliata, 1981 (Cumacea): a new reproductive pattern. Journal of Crustacean Biology 11:113-122.

Sarradin P-M, Caprais J-C, Riso R, Kerouel R, Aminot A. 1999. Chemical environment of the hydrothermal mussels communities in the Lucky Strike and Menez Gwen vent fields, MAR. Cahiers de Biologie Marine 40:93-104.

Sars GO. 1865. Om den aberrante krebsdygruppe Cumacea og dens nordiske Arter. Forhandlinger i Videnskaps-Selskapet in Kristiania 1864:128-208.

Smith SI. 1880. Notes on Crustacea collectd by Dr. G.M. Dawson at Vancouver and the Queen Charlotte Islands. Report of the Geological Survey of Canada, 1878-1879 Appendix D: 206-217. 
Tafe DJ, Greenwood JG. 1996. The Bodotriidae (Crustacea: Cumacea) of Moreton Bay, Queensland. Memoirs of the Queensland Museum 39(2):391-482.

Van Dover CL. 2000. The Ecology of Deep-Sea Hydrothermal Vents. Princeton Univ. Press. 424 pages.

Warén A. 1996. New and little known Mollusca from Iceland and Scandinavia, part 3. Sarsia 81:197-245.

Warén A, Bouchet P. 2001. Gastropoda and Monoplacophora from hydrothermal vents and seeps; new taxa and records. The Veliger 44:116-231.

Watling L. 1991. Rediagnosis and revision of some Nannastacidae (Crustacea: Cumacea). Proceedings of the Biological Society of Washington 104(4):751-757.

Watling L, Gerken S. 2001. Humesiana, a remarkable new cumacean genus from the caribbean sea. Journal of Crustacean Biology 21:243-248.

Weiss R, Lonsdale P, Lupton J, Bainbridge A, Craig H. 1977. Hydrothermal plumes in the Galapagos Rift. Nature 267(5612):600-603.

Wolff T. 2005. Composition and endemism of the deep-sea hydrothermal vent fauna. Cahiers de Biologie Marine 46:97-104. 
Table 1. Station data for the samples yielding Cumacea. The active chimneys or vent sites closest to each sampling location are referred in brackets using the names given during French and American cruises (see Desbruyères et al. 2001).

\begin{tabular}{|c|c|c|c|c|c|c|c|c|}
\hline Cruise & $\begin{array}{l}\text { Station } \\
\text { /sample }\end{array}$ & Date & Latitude & Longitude & $\begin{array}{l}\text { Depth } \\
\text { (m) }\end{array}$ & Lithology & Location & Species \\
\hline PICO & SMAC-B9 & 5.07 .1998 & $37^{\circ} 17.358^{\prime} \mathrm{N}$ & $32^{\circ} 16.511^{\prime} \mathrm{W}$ & 1690 & & $\begin{array}{l}\text { SE area (Tour } \\
\text { Eiffel) near active } \\
\text { chimneys }\end{array}$ & Thalycrocuma sarradini \\
\hline PICO & SMAC-C6 & 6.07 .1998 & $37^{\circ} 17.357^{\prime} \mathrm{N}$ & $32^{\circ} 16.479^{\prime} \mathrm{W}$ & 1705 & & $\begin{array}{l}\text { SE area (Tour } \\
\text { Eiffel) near active } \\
\text { chimneys }\end{array}$ & Thalycrocuma sarradini \\
\hline TTR10 & AT248Gr & 1.08 .2000 & $37^{\circ} 17.425^{\prime} \mathrm{N}$ & $32^{\circ} 16.509^{\prime} \mathrm{W}$ & 1665 & Sulphide & SE area & Procampylaspis sp. \\
\hline TTR10 & AT250Gr & 1.08 .2000 & $37^{\circ} 17.275^{\prime} \mathrm{N}$ & $32^{\circ} 16.525^{\prime} \mathrm{W}$ & 1704 & $\begin{array}{l}\text { Volcanic: } \\
\text { hyaloclastic rocks }\end{array}$ & $\begin{array}{l}\text { SE area (Tour } \\
\text { Eiffel) near active } \\
\text { chimneys }\end{array}$ & Thalycrocuma sarradini \\
\hline TTR10 & AT251Gr & 1.08 .2000 & $37^{\circ} 17.356^{\prime} \mathrm{N}$ & $32^{\circ} 16.657^{\prime} \mathrm{W}$ & 1685 & Sulphide & SE area & Thalycrocuma sarradini \\
\hline TTR10 & AT255Gr & 2.08 .2000 & $37^{\circ} 17.503^{\prime} \mathrm{N}$ & $32^{\circ} 16.610^{\prime} \mathrm{W}$ & 1680 & Hydrothermal slab & SE area & Thalycrocuma sarradini \\
\hline TTR10 & AT271Gr & 4.08 .2000 & $37^{\circ} 17.461^{\prime} \mathrm{N}$ & $32^{\circ} 16.924^{\prime} \mathrm{W}$ & 1712 & $\begin{array}{l}\text { Sulphide: } \\
\text { low temperature, } \\
\text { active }\end{array}$ & $\begin{array}{l}\text { NW area (Nuno), } \\
\text { diffuse venting }\end{array}$ & Thalycrocuma sarradini \\
\hline TTR10 & AT279Gr & 5.08 .2000 & $37^{\circ} 17.400^{\prime} \mathrm{N}$ & $32^{\circ} 16.625^{\prime} \mathrm{W}$ & 1703 & $\begin{array}{l}\text { Volcanic: high } \\
\text { vesicularity lava }\end{array}$ & SE area $(\mathrm{Y} 3)$ & Thalycrocuma sarradini \\
\hline ATOS & ML3-7 & 3.07 .2002 & $37^{\circ} 17.539^{\prime} \mathrm{N}$ & $32^{\circ} 16.404^{\prime} \mathrm{W}$ & 1630 & & $\begin{array}{l}\text { NE area (Sintra) } \\
\text { between two active } \\
\text { chimneys }\end{array}$ & Bathycuma brevirostre \\
\hline ATOS & ML3-12 & 3.07 .2002 & $37^{\circ} 17.539^{\prime} \mathrm{N}$ & $32^{\circ} 16.404^{\prime} \mathrm{W}$ & 1630 & & $\begin{array}{l}\text { NE area (Sintra) } \\
\text { between two active } \\
\text { chimneys }\end{array}$ & Makrokylindrus sp. \\
\hline ATOS & ML3-18 & 3.07 .2002 & $37^{\circ} 17.539^{\prime} \mathrm{N}$ & $32^{\circ} 16.404^{\prime} \mathrm{W}$ & 1630 & & $\begin{array}{l}\text { NE area (Sintra) } \\
\text { between two active } \\
\text { chimneys }\end{array}$ & Thalycrocuma sarradini \\
\hline ATOS & ML3-19 & 3.07 .2002 & $37^{\circ} 17.539^{\prime} \mathrm{N}$ & $32^{\circ} 16.404^{\prime} \mathrm{W}$ & 1630 & & $\begin{array}{l}\text { NE area (Sintra) } \\
\text { between two active } \\
\text { chimneys }\end{array}$ & Thalycrocuma sarradini \\
\hline TTR12 & AT425Gr & 26.08 .2002 & $37^{\circ} 20.465^{\prime} \mathrm{N}$ & $32^{\circ} 16.437^{\prime} \mathrm{W}$ & 2072 & $\begin{array}{l}\text { Volcanic: massive } \\
\text { lava }\end{array}$ & $\begin{array}{l}\text { Outside the vent } \\
\text { field }\end{array}$ & Cyclaspis longicaudata \\
\hline TTR12 & AT428Gr & 26.08 .2002 & $37^{\circ} 17.289^{\prime} \mathrm{N}$ & $32^{\circ} 16.522^{\prime} \mathrm{W}$ & 1716 & Hydrothermal slab & $\begin{array}{l}\text { SE area (Chimiste) } \\
\text { near active } \\
\text { chimney }\end{array}$ & Thalycrocuma sarradini \\
\hline TTR12 & AT436Gr & 29.08 .2002 & $37^{\circ} 17.300^{\prime} \mathrm{N}$ & $32^{\circ} 16.563^{\prime} \mathrm{W}$ & 1709 & Hydrothermal slab & $\begin{array}{l}\text { SE area (Chimiste) } \\
\text { near active } \\
\text { chimney }\end{array}$ & Thalycrocuma sarradini \\
\hline
\end{tabular}


Figure 1. Thalycrocuma sarradini gen. et sp. nov. female: A, habitus in lateral view; B, antenna 1; C, right mandible; D, left mandible; E, maxilula; F, maxiliped 1.

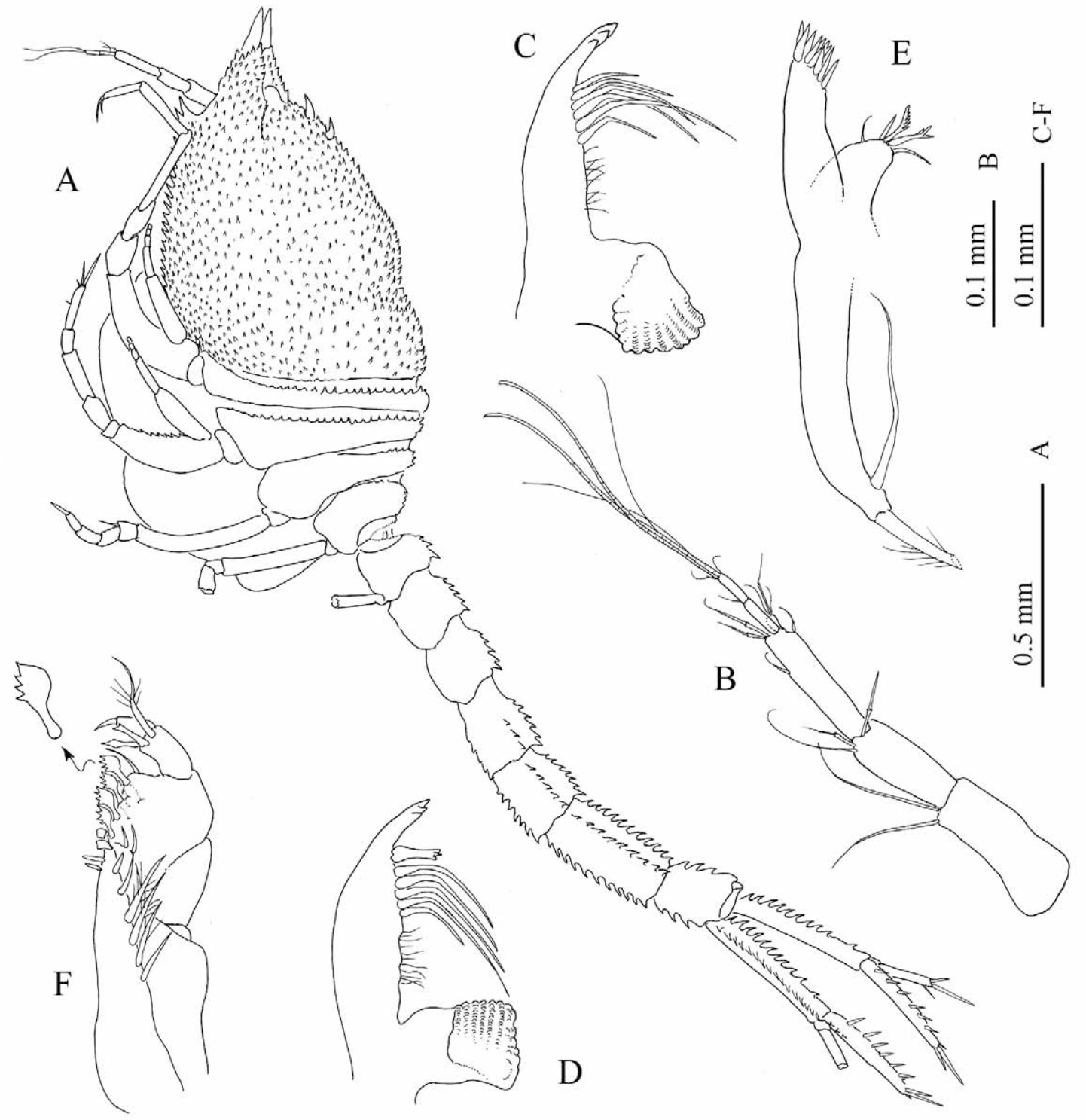


Figure 2. Thalycrocuma sarradini gen. et sp. nov. female: A, maxilliped 2; B, maxilliped 3; C, pereopod 1; D, pereopod 2.

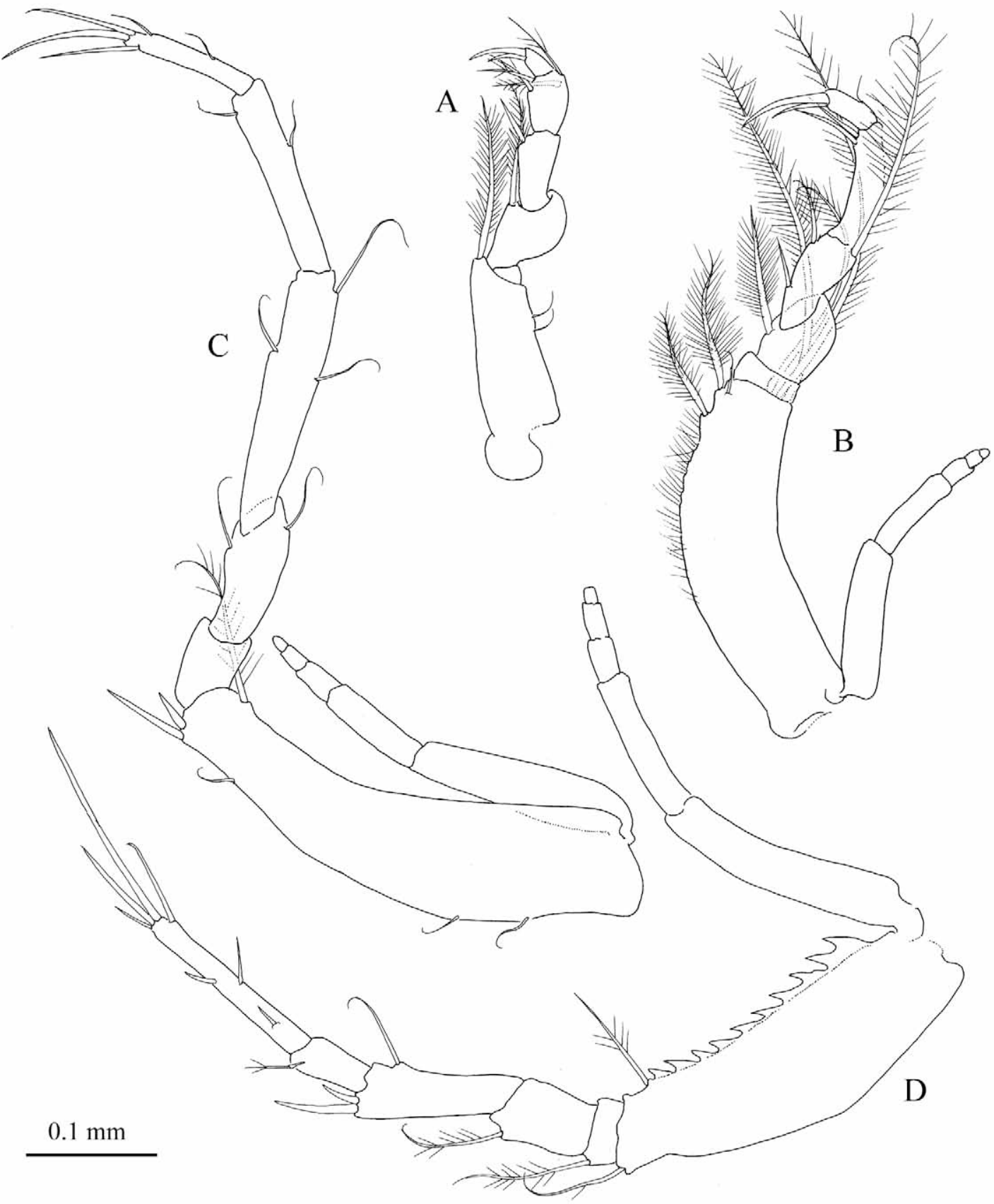


Figure 3. Thalycrocuma sarradini gen. et sp. nov. female: A, pereopod 3; B, pereopod 4; C, pereopod 5; D, uropod.
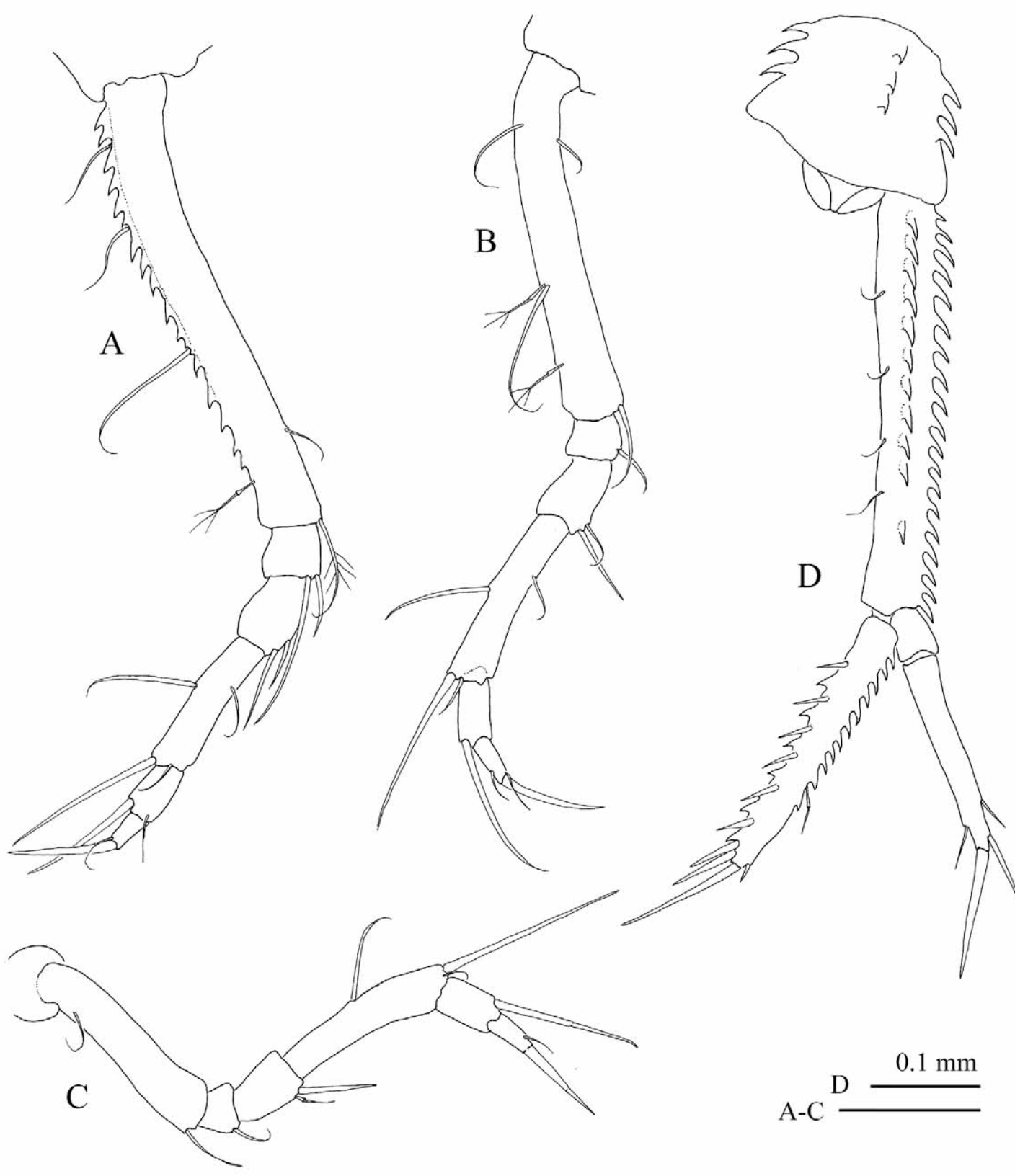

$\mathrm{A}-\mathrm{C} \stackrel{0.1 \mathrm{~mm}}{-}$ 
Figure 4. Thalycrocuma sarradini gen. et sp. nov. SEM photographs. Adult female: A, carapace cuticle showing the forwarded spines; B, pleonites 2 and 3 showing the longitudinal rows of spines. Adult male: C, cephalothorax in lateral view; D, carapace cuticle showing the forwarded spines; E, antennules between the first pair of pereopods; F, sensory setae attached on the ventral face of the article 3 of the peduncle of antennula.
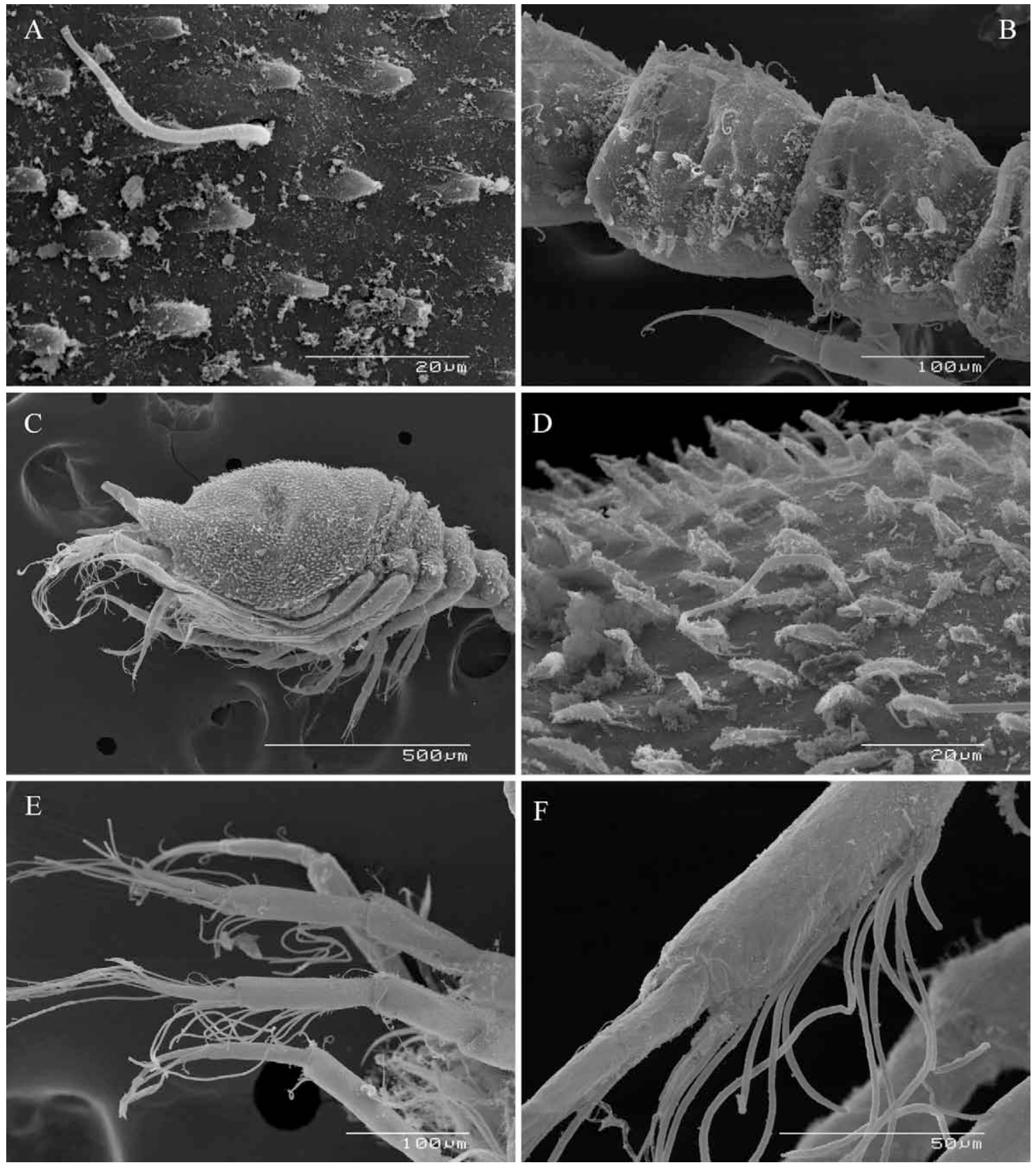
Figure 5. Thalycrocuma sarradini gen. et sp. nov. adult male: A, dorsal view of frontal lobe and pseudorostrum; B, antennula; C, antenna; D, pereopod 1.

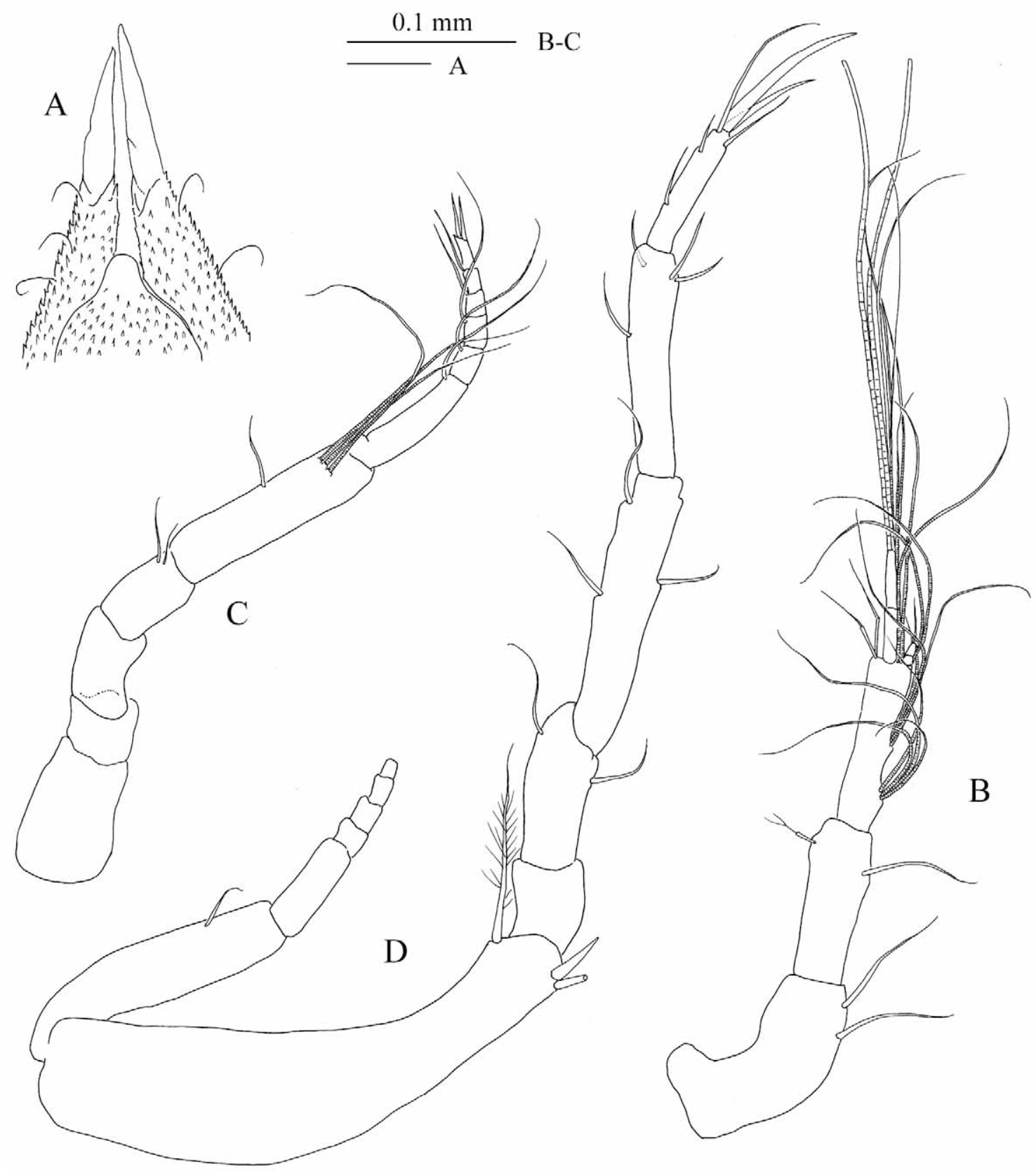


Figure 6. Thalycrocuma sarradini gen. et sp. nov. adult male: A, pereopod 2; B, pereopod 3; C, pereopod 4; D, pereopod 5.

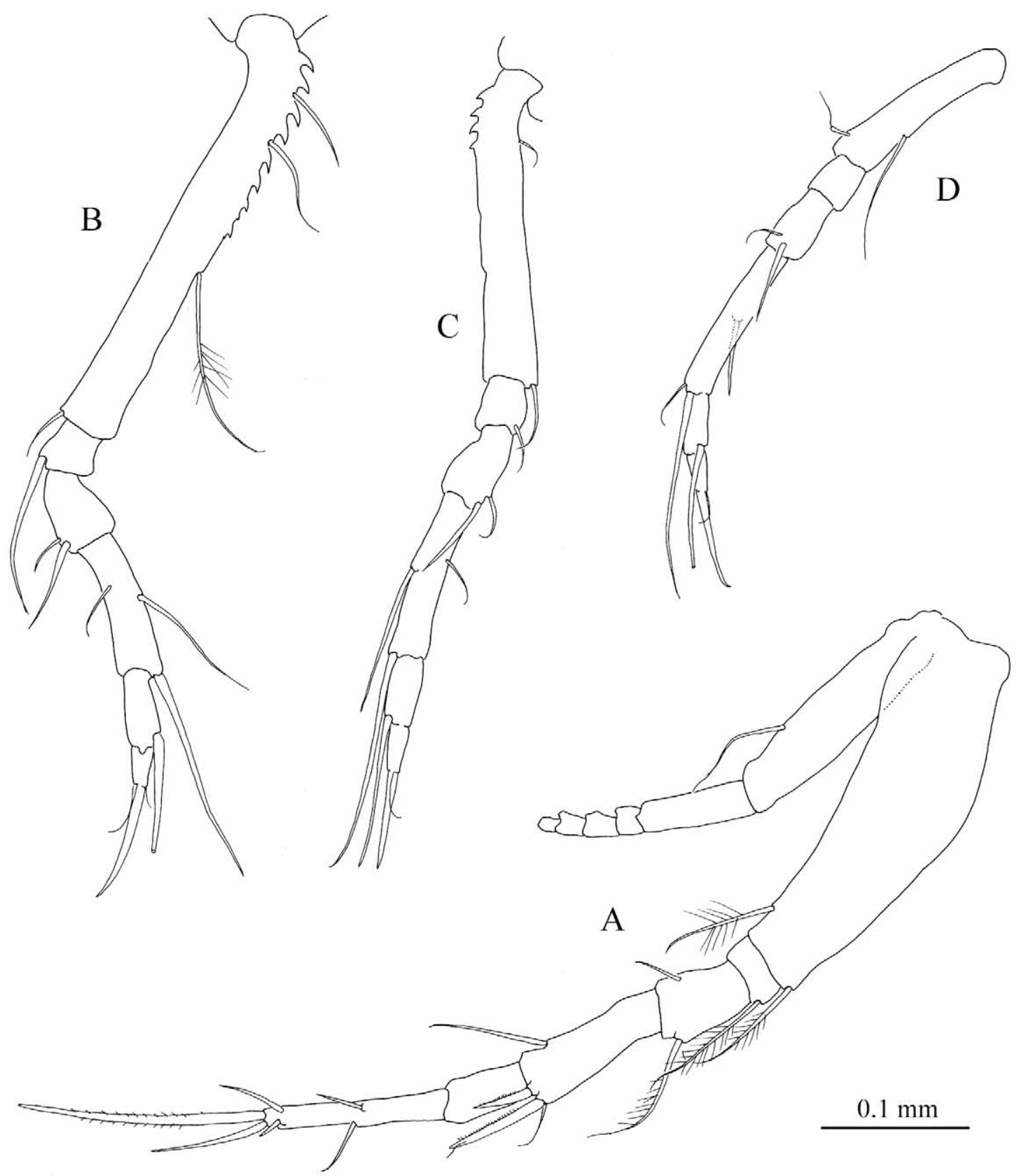

